\title{
AN IMPROVED ASSAY METHOD FOR NEUTRALIZING ANTIBODIES AGAINST INFLUENZA VIRUSES
}

\author{
By S. FAZEKAS DE ST GROTH, J. WITHELL AND K. J. LAFFERTY \\ From the Department of Microbiology, Australian National \\ University, Canberra
}

(With 4 Figures in the Text)

\begin{abstract}
Although influenza viruses as a group may boast the widest variety of assay procedures, when it comes to the accurate estimation of infective particles these methods become prohibitive in both cost and labour. Being quantal in nature, they require large numbers of replicates and, worse, are dogged by interhost variation of unknown magnitude. Tests for the neutralization of infectivity suffer from these shortcomings no less.

The first two objections can be met in practice by performing infectivity tests on bits of the surviving allantois (Fazekas de St Groth \& White, 1958a); and it could be shown that this method also eliminates gross variation in susceptibility within the host tissue (Fazekas de St Groth \& White, 1958b). As a further development, we report here the adaptation of the technique to the titration of antibodies.
\end{abstract}

\section{MATERIALS AND METHODS}

Virus. The ten strains of influenza virus were the same as used in an earlier study (Fazekas de St Groth \& Graham, 1954). Fluids harvested $42 \mathrm{hr}$. after allantoic infection with about $10^{2} \mathrm{ID}_{50}$ of the particular strain were pooled, distributed into $1.0 \mathrm{ml}$. ampoules, snap-frozen, and stored at $-70^{\circ} \mathrm{C}$.

Antisera. Rabbits were given $1 \cdot 0 \mathrm{ml}$. of high-titre allantoic fluid into each flank twice a week, and bled 1 month after the first injection. The sera were stored at $-10^{\circ} \mathrm{C}$., without any preservative. Fowls received a single intravenous dose, usually $1.0 \mathrm{ml}$. of an eluate. Depending on the immunizing virus, they were bled out after 3 to 12 days, always at the peak of antibody production.

Titration of antibody. Antihaemagglutinin tests were done in plastic trays. After inactivation, and destruction of the non-specific inhibitors by RDE-citrate- $65^{\circ} \mathrm{C}$. treatment (Fazekas de St Groth, 1949), twofold dilutions were made up with Takátsy-loops in $0.25 \mathrm{ml}$. of saline. A standard drop (0.025 ml.) of $5 \%$ fowl cells was then added, and finally a drop containing exactly four agglutinating doses of the test virus. The trays were shaken, and the pattern of cells read after $\frac{1}{2} \mathrm{hr}$. at room temperature.

Neutralization tests were done in 11-day eggs, by inoculating $0.05 \mathrm{ml}$. of the virus-antibody mixtures into the allantoic cavity. After 3 days' incubation at $35^{\circ} \mathrm{C}$. a small sample of allantoic fluid was tested for haemagglutinin. Usually groups of five eggs were used for each dilution. 
Mice, between the age of 5 and 10 weeks, received intranasally $0.05 \mathrm{ml}$. of the virus-antibody mixtures. The test was evaluated by the combined death-lesion score of Horsfall (1939).

Preparation of host tissue. Plastic trays (WHO model, $8 \times 10 \mathrm{cups}$ ) were filled with $0.25 \mathrm{ml}$. of Standard Medium per cup, and into each was dropped a $6 \times 6 \mathrm{~mm}$. square of eggshell with the chorioallantois attached. The constitution of the Standard Medium (s.M.) and full details of the technique of growing influenza viruses in bits of allantois-on-shell have been given earlier (Fazekas de St Groth \& White, 1958a).

\section{EXPERIMENTS}

\section{Effect of normal animal sera on the test}

While the general features of the infectivity test promised well for titrations of antibody, Fulton's experience (1952) counselled caution. He found, in a test with small snippets of the stripped chorioallantois, that the presence of animal seraeven when diluted over 1:1000-so affected the assay system that the multiplying virus never reached haemagglutinating levels. This forced him to expose the host tissue for a short time only to the mixture of virus and antibody, and the need to transfer and rinse such delicate fragments of tissue stood in the way of the wider acceptance of his method. We regarded it as our first task, therefore, to find out whether our host system was similarly affected by the presence of animal sera.

The type of experiment which will answer this question is essentially an infectivity test, where the main groups differ only in the constitution of the medium. Sera of normal animals without any immunological experience of influenza viruses were diluted in $3 \cdot 16$-fold (half $\log _{10}$ ) steps, and added to the medium containing the host tissue. The final concentrations ranged from $1: 31 \cdot 6$ to $1: 1000$. Two representative strains of influenza virus were used, MEL (A) and LEE (B). Dilutions of these were made in bulk, and then $0.025 \mathrm{ml}$. of each was added to sets of eight replicate cups. As further controls we also included some trays to which dilutions of heterologous antisera were added: anti-LEE to the MEL virus assays, and anti-MEL to the LEE titrations. The results were read after 2 or 3 days' incubation under standard conditions.

Simple inspection of Fig. 1 shows that, while some sera inhibited the appearance of haemagglutinin when present in the highest concentration tested, none of them had any effect when diluted to $1: 100$ or beyond. Statistical analysis confirms this conclusion: none of the titres obtained at serum concentrations of 1:100 or less are significantly lower than the controls, tested in the absence of serum. Heterologous sera behaved similarly. Thus, it is safe to say that at the levels used in practical tests neither normal nor heterologous sera have an effect on the infectivity of influenza viruses when assayed in our system.

This conclusion, taken together with the fact that the host system is sensitive to all influenza strains (Fazekas de St Groth \& White, 1958c), renders the titration of antibodies feasible, at least in theory. 


\section{The neutralization of infectivity}

In the first test dilutions of MEL (A) and LEE (B) virus were made up in chilled standard medium and mixed with equal volumes of specific antisera. The mixtures were kept for $\frac{1}{2} \mathrm{hr}$. at $0^{\circ} \mathrm{C}$., and then $0.05 \mathrm{ml}$. of each was added to a set of ten cups containing the host tissue. The trays were mounted on the shaking machine and
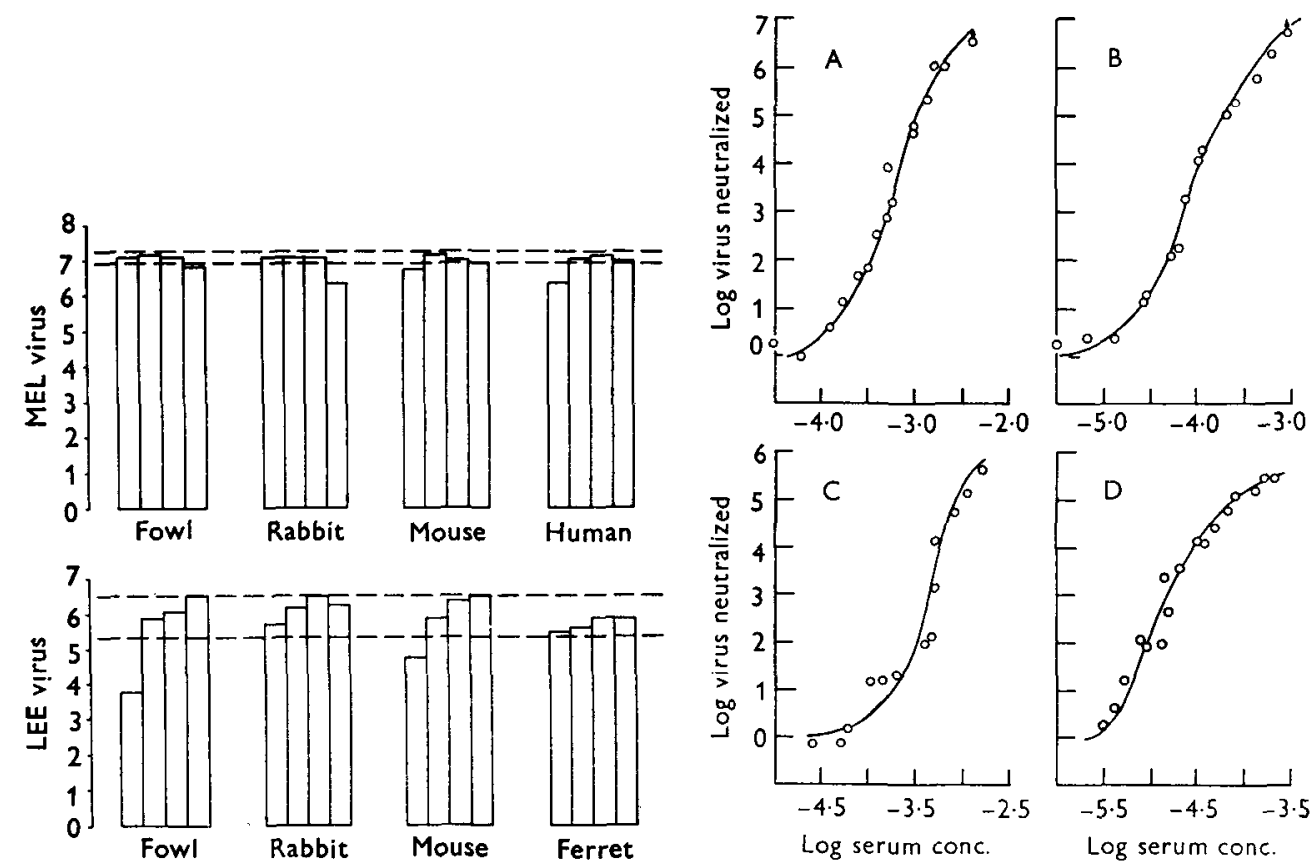

Fig. 2

Fig. 1. The infectivity of two strains of influenza virus in the presence of various concentrations of normal animal sera. The four steps of the abscissa correspond to final serum concentrations of $10^{-1 \cdot 5}, 10^{-2 \cdot 0}, 10^{-2 \cdot 5}, 10^{-3 \cdot 0}$, respectively. The ordinate gives the observed infectivity titres in $\log _{10}$ units. The $95 \%$ confidence interval of the infectivity titre in the absence of serum lies between the broken lines.

Fig. 2. The neutralization of the infectivity of two strains of influenza virus by their specific antisera. $A=$ anti-MEL fowl serum; central slope $=10^{6 \cdot 66} . \quad B=$ anti-MEL rabbit serum; central slope $=10^{5 \cdot 95}$. $\mathrm{C}=$ anti-LEE fowl serum; central slope $=10^{8 \cdot 62} . \mathrm{D}=$ anti-LEE rabbit serum; central slope $=10^{4 \cdot 42}$.

incubated for 2 days at $36^{\circ} \mathrm{C}$. Finally, the bits of tissue were removed, one drop of a $5 \%$ fowl red cell suspension added to each cup, and the pattern of settled cells observed. Agglutination of the cells was taken as the sign of infection, and the end-points were worked out by the method of Reed \& Muench. The results are presented in Fig. 2; the final concentration of antiserum is shown on the abscissa, and the number of $\mathrm{ID}_{50}$ neutralized on the ordinate.

Antisera from both rabbits and fowls neutralize the infectivity of the homologous virus. As the effect is still significant at serum concentrations of the order of $1: 100,000$, the reaction must be regarded as specific, since the same sera do not influence the infectivity of the heterologous strain in concentrations a thousand 
times higher. The dose-response curves are of sigmoid shape with a central slope much steeper than unity, and these slopes vary for different virus-antibody combinations. Apart from the very high titres, the general behaviour is thus found to be the same as seen in neutralization tests with influenza viruses in other systems (Tyrrell \& Horsfall, 1953).

\section{Standardization of the technique}

As, after all, the assay of neutralizing antibodies is but a modified infectivity test, only those steps need be tested experimentally which are peculiar to it, or which are likely to alter the basic conditions of infectivity tests. Such were studied over the range expected to be of practical interest.

Pre-incubation of virus and antibody. All strains of influenza virus are highly sensitive to inactivation by heat. For quantitative work it is essential therefore to keep all dilutions of virus in an ice-bath, where the loss of infectivity is negligible over the period of a standard test. The addition of a small volume (about $10 \%$ ) of chilled fluid to the medium of the host tissue is, in our experience, without any effect on either its survival or susceptibility to infection.

As it is convenient to make up first all serum dilutions to be tested and then mix them with the appropriate dose of virus, the time between starting and finishing the stage of inoculation may extend over an hour or more. It has been shown that such a delay before infection makes no difference to the susceptibility of the tissue (Fazekas de St Groth \& White, 1958a); it could, however, influence the outcome of a neutralization test if the final titres depended on the time allowed for interaction of virus and antibody before coming into contact with the host cells.

In an experiment dilutions of rabbit anti-LEE serum were mixed with varying doses of LEE virus, and placed in an ice-bath. After 10, 20, 40, 80 and 160 min. a set of trays was inoculated with $0.05 \mathrm{ml}$. of each mixture per cup, incubated for 2 days at $36^{\circ} \mathrm{C}$., and the results evaluated in the usual manner.

\section{Table 1. The effect of pre-incubation on neutralizing titres*}

LEE (B) virus and hyperimmune rabbit anti-LEE serum.

\begin{tabular}{|c|c|c|c|c|c|}
\hline \multirow{2}{*}{$\begin{array}{c}\text { Period of } \\
\text { pre-incubation } \\
\text { (min.) }\end{array}$} & \multicolumn{4}{|c|}{ Dilution of antiserum } & \multirow{2}{*}{$\begin{array}{c}\text { Virus } \\
\text { control } \\
\left(\log _{10} \mathrm{ID}_{50}\right)\end{array}$} \\
\hline & $10^{-3 \cdot 7}$ & $10^{-4 \cdot 0}$ & $10^{-4 \cdot 3}$ & $10^{-4 \cdot 6}$ & \\
\hline 10 & $4 \cdot 90$ & $4 \cdot 90$ & $3 \cdot 40$ & $3 \cdot 25$ & $5 \cdot 50$ \\
\hline 20 & $4 \cdot 90$ & $4 \cdot 75$ & $3 \cdot 25$ & $2 \cdot 42$ & $5 \cdot 71$ \\
\hline 40 & $4 \cdot 90$ & $4 \cdot 58$ & $3 \cdot 25$ & $2 \cdot 22$ & $5 \cdot 91$ \\
\hline 80 & $4 \cdot 90$ & $4 \cdot 75$ & $3 \cdot 40$ & $2 \cdot 77$ & $5 \cdot 85$ \\
\hline 160 & $4 \cdot 90$ & $4 \cdot 90$ & $4 \cdot 90$ & $3 \cdot 23$ & $5 \cdot 29$ \\
\hline Mean titre & $4 \cdot 90$ & $4 \cdot 78$ & $3 \cdot 64$ & $2 \cdot 78$ & $5 \cdot 65$ \\
\hline
\end{tabular}

* The neutralizing titre of a particular serum dilution is that dose of virus (in $\log _{10}$ units) of which only one $\mathrm{ID}_{50}$ survives.

Clearly, within the limits of statistical variation, the titres are the same in each group, that is, the length of pre-incubation has no influence on the outcome of the neutralization test. Although this conclusion has been confirmed in several further 
tests, it should be added that with some hyperimmune sera we have found that the titres tend to creep up after the second hour. As this phenomenon is one of the manifestations of characteristic qualitative differences between the initial and the anamnestic immune response, we propose to deal with it in a later paper. For everyday use the rule of thumb still holds that between 10 and $60 \mathrm{~min}$. the length of pre-incubation at $0^{\circ} \mathrm{C}$. makes no difference to the neutralization test.

The period of incubation. Even in straight infectivity tests some strains of influenza virus have to be incubated for 3 instead of the usual 2 days, as the titres often keep rising up to $60 \mathrm{hr}$. after inoculation into the allantois. In neutralization tests this behaviour is almost the rule, and the reading of results after 3 days has become general. The reason, it is usually assumed, lies in the fact that part of the yield from cells initially infected is neutralized by the antibody present in the medium, and thus the starting rate of multiplication may be much slower than it would be in the absence of antibody. The phenomenon is of practical importance because the neutralizing effect of antisera is always expressed as a relative quantity, that is, as the ratio of observed survival compared to the titre obtained in the absence of antibody. If assays are truncated at a point in time where the controls have reached maximum titres while test groups have not, the effect of antibody will be overestimated. Depending on the system, the error so arising may be considerable.

Whether bits of the surviving allantois behave in this respect as do whole eggs, was determined in the following experiment. Several dilutions of anti-MEL and anti-LEE sera were mixed with doses of the homologous virus ranging from 1 to $10^{6} \mathrm{ID}_{50}$, and inoculated into quadruplicate trays, with ten parallel cups per dilution. One-half of the trays was taken down after $48 \mathrm{hr}$., and the rest after $72 \mathrm{hr}$. The results are plotted in Fig. 3.
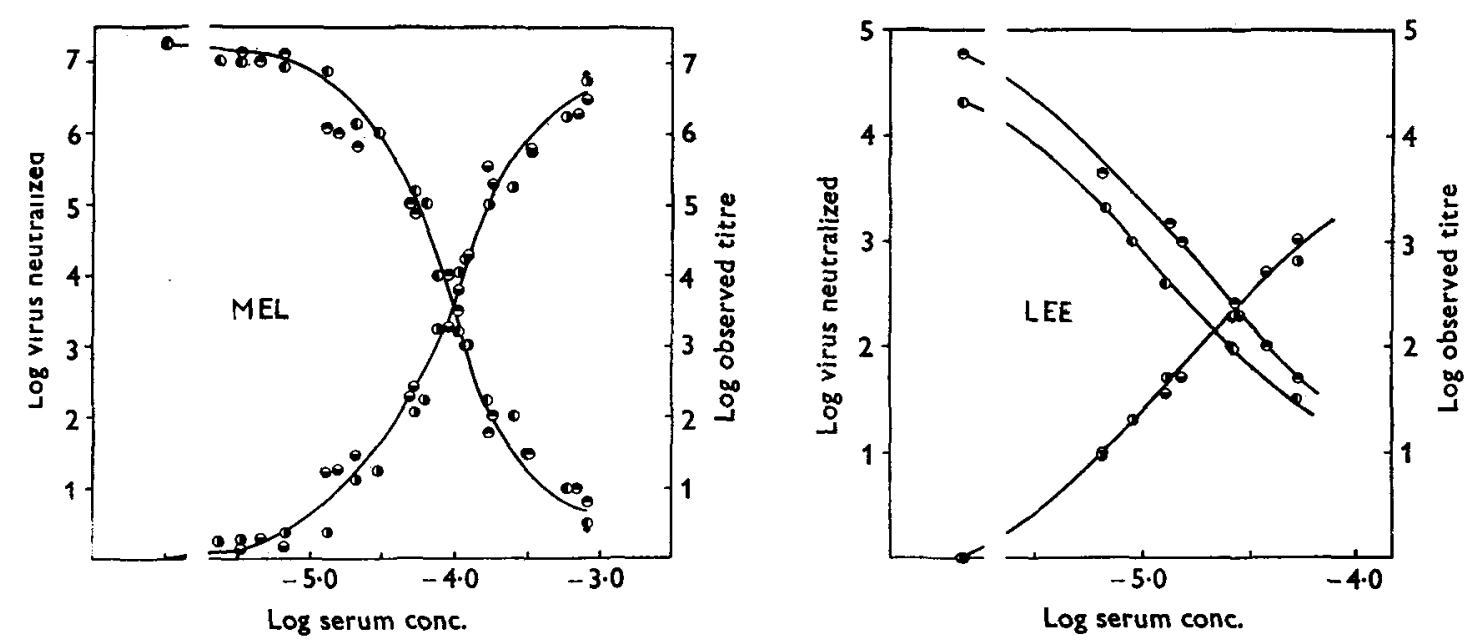

Fig. 3. The neutralization of two strains of influenza virus after different periods of incubation. The right-hand scales on the ordinate refer to the curves with the negative slopes, and show the infectivity titres at the various concentrations of serum. The left-hand scales show the neutralizing titres ( $=\log \mathrm{ID}_{50}$ in absence of serum- $\log \mathrm{ID}_{5_{0}}$ in presence of serum). The antiMEL and anti-LEE sera came from hyperimmune rabbits. The symbols halved vertically are $48 \mathrm{hr}$. readings, those halved horizontally are $72 \mathrm{hr}$. readings. 
In the case of MEL virus, the rapidly multiplying strain, there is no difference between titres after 2 or 3 days. This holds for both the neutralization trays and the controls of infectivity. The decision therefore to read tests after 2 days is natural. LEE virus, on the other hand, shows a rise of $0.4 \mathrm{log}$ units between the second and third day. Unlike tests on the whole allantois, however, the rise here characterizes viral multiplication not only in the presence of antibody but also the control sets. In operational terms this means that as far as neutralizing titres go, nothing is gained by reading the tests later than 2 days. The longer period of incubation becomes mandatory only if absolute measurements are to be made, i.e. in an investigation of the mechanism of antibody action. Hence, the recommended period of incubation is 2 days for the routine titration of sera, irrespective of the strain of virus used.

This discrepancy between the behaviour of whole eggs and surviving fragments is only one of the many found in comparing these systems; their detailed study and interpretation is left to a later paper.

The volumes of medium and of inoculum. When tested on surviving bits of the allantois, the infectivity titre of a given preparation of influenza virus is the same whether contained in a large or small volume of fluid, or inoculated into a large or small volume of growth medium (Fazekas de St Groth \& White, 1958a). In neutralization tests the outcome can be independent of the test volume only if the virusantibody complex is non-dissociable, i.e. if the assay would simply determine the amount of virus left free in the test-tube where the reagents were originally brought together. If the law of mass action holds, the neutralizing titre should be inversely related to the volume of fluid used in the test. The practical consequence of these alternatives is that in the first case the neutralizing power of an antiserum would be uniquely defined by the number of virus particles it was able to render noninfective, irrespective of the test conditions. In the second case such a definition would be meaningless as the outcome of an assay would depend not only on the absolute quantities of the reagents but also on their partial concentrations, that is, on conditions of the test.

Neutralization experiments in plastic trays are especially suitable to settle this problem since, unlike in whole eggs, the volume of the medium can be readily varied. We made up mixtures of virus and antibody, and after $\frac{1}{2} \mathrm{hr}$. pre-incubation at $0^{\circ} \mathrm{C}$. inoculated $0.05 \mathrm{ml}$. volumes into cups containing 2.00 or $0.25 \mathrm{ml}$. of standard medium, respectively. The size of the host tissue, as well as all other details of the test were the same for the two sets. Fig. 4 shows the results.

For each combination of antigen and antibody the neutralizing titres were consistently lower when the test was done in the larger volume of medium. This finding has far-reaching theoretical implications, which will be followed up later. On the practical plane it demands that neutralizing titres should not be compared unless all conditions of the test, including the dose of antigen and the volume of growth medium are identical, and that titres be expressed in terms of final concentrations and not, as is the habit, of the volume in which virus and antibody were first brought together.

The corollary of this view is that the neutralizing effect should not depend on 
the quantities of virus and antibody brought together in the reaction tube, nor on the volume of this mixture inoculated, as long as the final concentrations for a given test system are the same. The experimental evidence on this point is quite unequivocal: the neutralizing titres were always found constant for a given final concentration of the reagents, whatever the route or intermediate steps by which these concentrations were reached.

\section{Comparison of the method with in vivo neutralization tests and antihaemagglutinin titrations}

To establish the new assay in relation to the orthodox techniques, seven representative strains of virus were chosen: two of Type A, two of subtype A-prime, two of Type B, and a strain of swine influenza. Each of these was tested at two levels (about $10^{4}$ and $10^{2} \mathrm{ID}_{50}$ ) against specific antisera prepared in rabbits or fowls. All the rabbit sera were hyperimmune; the fowl sera were the response to a single intravenous injection of antigen. Dilutions of the inactivated sera were brought together with an equal volume of the appropriate dose of virus. After $30 \mathrm{~min}$. at $0^{\circ} \mathrm{C}$., $0.05 \mathrm{ml}$. volumes were inoculated either allantoically into 11-day embryonated eggs, or into cups containing a bit of allantois-on-shell bathed in $0.30 \mathrm{ml}$. of s.M.

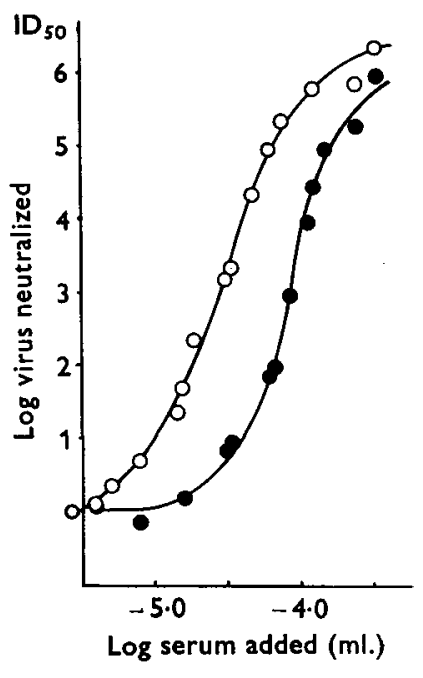

Fig. 4. The effect of the test volume on neutralization curves. Anti-MEL rabbit serum tested in $2.00 \mathrm{ml}$. volumes of medium (O) and $0.30 \mathrm{ml}$. volumes $(\mathrm{O})$. The results were read after $48 \mathrm{hr}$. in the case of A-strains, and after $72 \mathrm{hr}$. in the case of the more slowly growing B-viruses. Only four of the seven strains were adapted to grow in mice. These viruses were mixed with similar doses of antibody as used in eggs, and $0.05 \mathrm{ml}$. of the mixtures was instilled nasally to groups of five animals. Specific deaths were noted, and the survivors autopsied on the seventh day after inoculation. Neutralizing titres were worked out by relating the average lung lesions to those found in groups of control mice receiving dilution of virus only. In the antihaemagglutinin tests four agglutinating doses of virus were used, and the results read after $\frac{1}{2} \mathrm{hr}$. standing at room temperature.

The first conclusion from Table 2 is that the antihaemagglutinin titres are not simply related to the neutralizing power, i.e. there is no way of transforming one into the other by adding or subtracting a constant value or by multiplying by a constant factor. This confirms the general experience of previous workers who compared the two basic techniques for measuring antibodies against influenza viruses, and it can now be extended to neutralization tests performed on the surviving allantois.

Neither do the three in vivo methods give the same answer. The titres in whole eggs are invariably lower than in surviving bits taken from the same batch of eggs. The slope of the line passing through the two points of virus concentration is, on the other hand, steeper in whole eggs in every instance in which it could be determined. This renders also these two tests incommensurable. The neutralizing 
titres obtained in mice lie closer to those found in the tray test, wut une cumerence both in end-point and slope is sufficient to set even these two apart. In this connexion it is important to note that the slopes of the neutralization curves often differ even within one strain tested in the same host system. These differences are

Table 2. Comparative titration of antisera

\begin{tabular}{|c|c|c|c|c|c|c|}
\hline \multirow{2}{*}{$\begin{array}{l}\text { Strain } \\
\text { of virus }\end{array}$} & \multirow[b]{2}{*}{ Antiserum } & \multicolumn{4}{|c|}{ Neutralization tests } & \multirow{2}{*}{$\begin{array}{c}\text { Antihaem } \\
\text { agglutini } \\
\text { test }\end{array}$} \\
\hline & & Dose & In eggs & In trays & In mice & \\
\hline PR 8 (A) & Rabbit & $\begin{array}{l}1: 1 \\
1: 100\end{array}$ & $\left.\begin{array}{l}1 \cdot 67 \\
2 \cdot 67\end{array}\right\}(3 \cdot 21)$ & $\left.\begin{array}{r}2.50 \\
>4.5\end{array}\right\}(3.31)$ & $\left.\begin{array}{r}2.71 \\
>4.0\end{array}\right\}(2.92)$ & $4 \cdot 22$ \\
\hline \multirow[t]{2}{*}{ MEL (A) } & Rabbit & $\begin{array}{l}1: 1 \\
1: 100\end{array}$ & $\left.\begin{array}{l}1 \cdot 55 \\
1 \cdot 90\end{array}\right\}(4 \cdot 17)$ & $\left.\begin{array}{l}2 \cdot 72 \\
3 \cdot 11\end{array}\right\}(4 \cdot 32)$ & $\left.\begin{array}{l}1 \cdot 72 \\
2 \cdot 95\end{array}\right\}(4 \cdot 62)$ & $3 \cdot 77$ \\
\hline & Fowl & $\begin{array}{l}1: 1 \\
1: 100\end{array}$ & $\left.\begin{array}{l}<0.5 \\
<0.5\end{array}\right\}(3.00)$ & $\left.\begin{array}{l}1.50 \\
1.77\end{array}\right\}(3.25)$ & - & $3 \cdot 40$ \\
\hline \multirow[t]{2}{*}{$\mathrm{CAM}\left(\mathrm{A}^{\prime}\right)$} & Rabbit & $\begin{array}{l}1: 1 \\
1: 100\end{array}$ & $\left.\begin{array}{l}1 \cdot 50 \\
1 \cdot 71\end{array}\right\}(5 \cdot 67)$ & $\left.\begin{array}{l}2 \cdot 50 \\
3 \cdot 50\end{array}\right\}(5 \cdot 77)$ & - & $3 \cdot 30$ \\
\hline & Rabbit & $\begin{array}{l}1: 1 \\
1: 100\end{array}$ & $\left.\begin{array}{l}1 \cdot 71 \\
2 \cdot 00\end{array}\right\}(5 \cdot 67)$ & $\left.\begin{array}{l}2 \cdot 28 \\
2 \cdot 92\end{array}\right\}(5 \cdot 77)$ & - & $3 \cdot 16$ \\
\hline \multirow[t]{2}{*}{ FMI $\left(A^{\prime}\right)$} & Rabbit & $\begin{array}{l}1: 1 \\
1: 100\end{array}$ & $\left.\begin{array}{l}0.70 \\
1.50\end{array}\right\}(3.97)$ & $\left.\begin{array}{l}2 \cdot 10 \\
3 \cdot 75\end{array}\right\}(3 \cdot 52)$ & - & $3 \cdot 75$ \\
\hline & Rabbit & $\begin{array}{l}1: 1 \\
1: 100\end{array}$ & $\left.\begin{array}{r}<0.5 \\
1.31\end{array}\right\}(3.97)$ & $\left.\begin{array}{l}2 \cdot 76 \\
4 \cdot 31\end{array}\right\}(3 \cdot 52)$ & - & $3 \cdot 88$ \\
\hline \multirow[t]{2}{*}{ LEE (B) } & Rabbit & $\begin{array}{l}1: 1 \\
1: 100\end{array}$ & $\left.\begin{array}{l}1 \cdot 50 \\
2 \cdot 50\end{array}\right\}(3 \cdot 88)$ & $\left.\begin{array}{r}2 \cdot 72 \\
>4 \cdot 5\end{array}\right\}(3 \cdot 48)$ & $\left.\begin{array}{r}2 \cdot 68 \\
>4 \cdot 0\end{array}\right\}(2 \cdot 36)$ & $3 \cdot 89$ \\
\hline & Fowl & $\begin{array}{l}1: 1 \\
1: 100\end{array}$ & $\left.\begin{array}{c}<0.5 \\
1.72\end{array}\right\}(3.88)$ & $\left.\begin{array}{l}2 \cdot 50 \\
3 \cdot 50\end{array}\right\}^{(3.48)}$ & - & $4 \cdot 04$ \\
\hline BON (B) & Rabbit & $\begin{array}{l}1: 1 \\
1: 100\end{array}$ & $\left.\begin{array}{l}<0.5 \\
<0.5\end{array}\right\}(5.07)$ & $\left.\begin{array}{l}1 \cdot 51 \\
2 \cdot 69\end{array}\right\}(4 \cdot 32)$ & - & $2 \cdot 75$ \\
\hline \multirow[t]{2}{*}{$\begin{array}{l}\text { (SW } \\
\text { (swine) }\end{array}$} & Rabbit & $\begin{array}{l}1: 1 \\
1: 100\end{array}$ & $\left.\begin{array}{l}1 \cdot 29 \\
1.71\end{array}\right\}(3 \cdot 73)$ & $\left.\begin{array}{l}1 \cdot 50 \\
3 \cdot 28\end{array}\right\}(4 \cdot 33)$ & - & $2 \cdot 75$ \\
\hline & Rabbit & $\begin{array}{l}1: 1 \\
1: 100\end{array}$ & $\left.\begin{array}{l}1 \cdot 29 \\
2 \cdot 20\end{array}\right\}(3 \cdot 73)$ & $\left.\begin{array}{l}2 \cdot 50 \\
3 \cdot 50\end{array}\right\}(4 \cdot 33)$ & $\left.\begin{array}{l}2 \cdot 42 \\
4 \cdot 00\end{array}\right\}(4 \cdot 55)$ & $3 \cdot 30$ \\
\hline
\end{tabular}

All titres are in $\log _{10}$ units. The bracketed figures show the infectivity titre of the undiluted challenging dose.

significant in terms of the error of antibody titrations, as the steepness of the slope has also the effect of rendering such tests much more accurate than are simple infectivity titrations. Indeed, the conclusion becomes inevitable that the neutralizing power of an antiserum cannot be expressed simply as a titre, i.e. in terms of a single parameter, because comparisons based on this criterion can be valid only if the slope of neutralization curves is constant.

Once recognized, this fact demands that informative tests should define the neutralization curve over its whole course or, minimally, at two points. The method proposed in the following section is designed to meet this requirement, and to estimate both position and slope of neutralization curves. 


\section{A two-point assay for neutralizing antibodies}

Principles. Owing to the steepness of neutralization curves, a test patterned on the $\beta$-procedure (i.e. constant antigen, variable antibody) is preferable. This choice both ensures that end-points are less likely to be missed, and makes for increased inherent accuracy. Although determination of a slope is the more accurate the wider apart the points of reference are, in practice the range has to be cut at both ends. The higher concentration of virus is best set at a level which is attainable by all strains of influenza virus, the level of the lower concentration so that it is not unduly influenced by random variation. Accordingly, $10^{5}-10^{6} \mathrm{ID}_{50}$ was chosen as the higher dose, and $10^{2}-10^{3} \mathrm{ID}_{50}$ as the lower.

The arrangement of the cups in the trays used in these tests $(8 \times 10$ cups $)$ suggested that the most suitable plan would be to have eight serum dilutions tested at two levels of virus concentration thus giving five replicates for each combination. In assays of an unknown serum three- or four-fold steps starting at $1: 10$ will cover the span of possible titres. The dilutions should be more closely spaced, of course, if there is any previous knowledge of the potency of the serum. Such a complete two-point test will require one tray, filled with host tissue derived from a single egg.

Practice. Trays are filled with $0.25 \mathrm{ml}$. of s.M. per cup, and one bit of membraneon-shell is placed in each cup. The trays are then returned to the incubator until inoculation.

Sera, diluted $1: 10$ in S.M. are inactivated at $62.5^{\circ} \mathrm{C}$. for 15 min. Starting with this 1:10 stock a set of eight dilutions is made up. For unknown sera $0.25 \mathrm{ml}$. volumes are carried into $0.54 \mathrm{ml}$. of s.M., giving a logarithmic series with increments of 0.5 units. Then $0.25 \mathrm{ml}$. volumes of each of these dilutions are transferred to a duplicate set of small test-tubes kept in an ice-bath.

The virus to be used is made up in chilled s.M. to contain approximately $10^{7} \mathrm{ID}_{50} / \mathrm{ml}$, and from this stock an accurate $1: 1000$ dilution is made up in a second tube.

The first row of serum dilutions receives $0.25 \mathrm{ml}$. per tube of the higher dose of virus, the second $0.25 \mathrm{ml}$. of the lower dose. The racks are then shaken and returned to the ice-bath for $\frac{1}{2} \mathrm{hr}$. Calibrated dropping pipettes $(0.025 \mathrm{ml}$. drops) are used to deliver the virus-serum mixtures on to the host tissue: each cup receives two drops $(0.05 \mathrm{ml}$.). If inoculation is started at the lowest concentration of serum, the same pipette may be used for one row of dilutions, i.e. to inoculate one-half of the tray. The inoculated trays are mounted and wrapped as described by Fazekas de St Groth \& White (1958a) under Methods, and placed on the shaker for $48 \mathrm{hr}$. at $36^{\circ} \mathrm{C}$. At the end of this period the bits of tissue-on-shell are removed, one drop of $5 \%$ fowl $\mathrm{RBC}$ is added to each cup, and the pattern of agglutination is read after $\frac{1}{2} \mathrm{hr}$. standing at room temperature.

The end-points for the higher and lower dose of virus (upper and lower half of tray) are computed by the method of Reed \& Muench. (It should be remembered that the concentration of serum is twelve times lower in the assay cup than it was in the tube of initial virus-antibody contact. Accordingly, the titres have to be multiplied by 12 , or 1.08 has to be added to the log titres.) The slope is obtained 
by the formula $s=3 /\left(T_{1}-T_{2}\right)$, where $s$ is the $\log$ slope, $T_{1}$ and $T_{2}$ are the two serum end-points read in the test.

The infectivity of the virus preparation is always determined in a parallel control test: eight $0.5 \log$ dilutions are made of the lower doses of virus, and these are inoculated into one tray (ten replicates per dilution).

Accuracy. Tests under this heading aimed to define what sources of variation need be considered when the technique is used as a laboratory routine, and what is the error arising from each of these factors. Although most of the answers could have been extracted from the results of various titrations done earlier, a further factorial experiment was designed to test not only the main effects but also their interactions.

Some titrations were done by using the same set of virus-antibody dilutions and delivering them with the same pipette to a number of trays; these will be called replicate tests, and estimate the inherent error of the method. To imitate the simultaneous titration of more than one sample, several starting dilutions of serum were made up, inactivated and diluted separately, giving several parallel sets of virusantibody mixtures. These parallel tests estimate the error due to variations in the technique of a single performer using the same reagents on the same day. Since all these tests were performed by each of us, the systematic difference between operators could be assessed; and by repeating the whole set on several days, the possible contribution of factors like variation between batches of eggs, differences in the rate of shaking, changes in outer temperature, the condition of glassware, etc., could be isolated. The factors thus included operators (3), days of performance (3), parallel tests (2), and replicate tests (4), that is seventy-two trays in all. As each tray contained a complete two-point assay, the dose of virus may be regarded as a further contrast, raising the degrees of freedom to 143 for the simple neutralization tests, with forty cups of tissue contributing to each entry. The results (log titres and log slopes) are analysed in Tables $3 a$ and $b$.

The determination of neutralizing titres is considerably more accurate than the straight test for infectivity in the same system (Fazekas de St Groth \& White, $1958 b$ ). This is due entirely to the steep slope of the dose-response curve. In terms of the small basic variance, additional sources of error show up as significant in the analysis of variance. Thus, while there is no difference in the technique of the three operators here tested, each of them introduced further variation when making up his own series of serum dilutions (see 'parallel tests'). There is also a hint of interaction here $(O \times P)$. Yet these differences, although statistically detectable, are of little practical importance, the mean difference between parallel tests being only $0.087 \mathrm{log}$ units. The absolute difference between tests performed on different days is of the same order, but once more beyond what could be expected by chance. The information, perhaps more directly useful, is the error associated with tests done under various circumstances. These have been calculated from the data of both Tables $3 a$ and $b$, and are given in Table 4 .

The slopes of neutralization curves can be estimated with a precision greatly inferior to that of either infectivity or neutralization tests. This is, in a sense, the price paid for the greater accuracy of points estimated along the antibody scale. 
Table $3 a$. The reproducibility of neutralization tests

Analysis of variance on end-points.

Source of variation

Dose of virus (D)

Day of performance $(T)$

Operators (O)

Parallel tests $(\mathrm{P})$

Interactions

$$
\begin{aligned}
& \mathrm{D} \times \mathrm{T} \\
& \mathrm{D} \times \mathrm{O} \\
& \mathrm{D} \times \mathrm{P} \\
& \mathrm{T} \times \mathrm{O} \\
& \mathrm{T} \times \mathrm{P} \\
& \mathrm{O} \times \mathrm{P} \\
& \mathrm{D} \times \mathrm{T} \times \mathrm{O} \\
& \mathrm{D} \times \mathrm{T} \times \mathrm{P} \\
& \mathrm{D} \times \mathrm{O} \times \mathrm{P} \\
& \mathrm{T} \times \mathrm{O} \times \mathrm{P} \\
& \mathrm{D} \times \mathrm{T} \times \mathrm{O} \times \mathrm{P}
\end{aligned}
$$

Replicate tests (error)

\section{Degrees}

of freedom

$$
1
$$

2

2

1

2

2

1

4

2

2

4

2

2

4

4

108

143

$\begin{array}{rr}\text { Mean } & \text { Variance } \\ \text { square } & \text { ratio } \\ \mathbf{2 6 \cdot 0 2 7 0} & \mathbf{1 9 3 5 \cdot 0 9} \\ \mathbf{0 \cdot 0 7 8 5} & \mathbf{5 \cdot 8 4} \\ 0 \cdot 0235 & 1 \cdot 75 \\ 0 \cdot 2756 & 20 \cdot 49\end{array}$

$0.0348 \quad 3.59$

0.0135

0.0006

0.0151

0.0266

0.0484

$0 \cdot 0123$

0.0067

0.0357

0.0213

0.0112

0.0134

1.00

$0 \cdot 04$

$1 \cdot 12$

I.98

$3 \cdot 60$

$0 \cdot 91$

$0 \cdot 50$

$2 \cdot 65$

$1 \cdot 58$

$0 \cdot 83$
Significance

$$
P \ll 0.001
$$

$0.01>P>0.001$

$$
P<\overline{0.001}
$$

$0 \cdot 05>P>0.01$

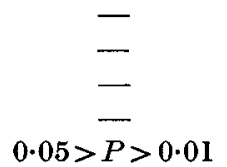

$0 \cdot 05>P>0 \cdot 01$

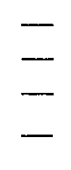

Table $3 b$. The reproducibility of neutralization tests

Analysis of variance on slopes.

Source of variation

Day of performance $(\mathrm{T})$

Operators (O)

Parallel tests (P)

Interactions

$$
\begin{aligned}
& \mathrm{T} \times \mathrm{O} \\
& \mathrm{T} \times \mathrm{P} \\
& \mathrm{O} \times \mathrm{P} \\
& \mathrm{T} \times \mathrm{O} \times \mathrm{P}
\end{aligned}
$$

Replicate tests (error)

\section{Degrees \\ of freedom}

$$
2
$$

2

1

4
2

\begin{tabular}{|c|c|c|c|c|}
\hline \multicolumn{3}{|c|}{ Source of variation } & \multicolumn{2}{|c|}{ Standard error } \\
\hline Operator & Day of testing & Reagents & End-point & Slope \\
\hline Same & Same & $\begin{array}{l}\text { Same } \\
\text { Different }\end{array}$ & $\begin{array}{l}0 \cdot 118 \\
0.132\end{array}$ & $\begin{array}{l}0.649 \\
0.649\end{array}$ \\
\hline & Different & $\begin{array}{l}\text { Same } \\
\text { Different }\end{array}$ & $\begin{array}{l}0.123 \\
0 \cdot 137\end{array}$ & $\begin{array}{l}0.678 \\
0.678\end{array}$ \\
\hline Different & Same & $\begin{array}{l}\text { Same } \\
\text { Different }\end{array}$ & $\begin{array}{l}0 \cdot 118 \\
0 \cdot 133\end{array}$ & $\begin{array}{l}0.656 \\
0.656\end{array}$ \\
\hline & Different & $\begin{array}{l}\text { Same } \\
\text { Different }\end{array}$ & $\begin{array}{l}0 \cdot 124 \\
0 \cdot 138\end{array}$ & $\begin{array}{l}0.688 \\
0.688\end{array}$ \\
\hline
\end{tabular}

2

2

4

54

71

Mean
square
$1 \cdot 4261$
$0 \cdot 6684$
$0 \cdot 0355$

$0 \cdot 6894$

0.3122

0.6919

0.5594

$0 \cdot 4101$

$\begin{gathered}\text { Variance } \\ \text { ratio } \\ \mathbf{3} \cdot 48 \\ \mathbf{1} \cdot 63 \\ 0 \cdot 09\end{gathered}$

$1 \cdot 68$

0.76

$1 \cdot 69$

$1 \cdot 36$

Table 4. Standard error of neutralizing titres and slopes under different conditions of testing

The errors were calculated from the data of Tables $3 a$ and $b$, and are expressed in $\log _{10}$ units. 
It also follows that the error will be a function of the estimated slope, and will reach a minimum when the error of virus and antibody titrations is equal. In the present case the mean slope was $10^{3.62}$ with a standard deviation of $10^{0.64}$. As a consequence small differences due to various factors or their interactions would pass unnoticed. Indeed, only the variation between tests performed on different days is suggestive of a true difference, and even this barely passes the $5 \%$ level of significance.

If an antiserum is titrated by the method developed above, the neutralizing titre will have an inherent error of \pm 0.118 , and the slope of \pm 0.649 . When the same serum is tested again on another day, by another operator using different reagents, the joint error of the two tests will have risen at most to \pm 0.138 and $\pm 0 \cdot 688$, respectively, that is by not more than a sixth of the basic error. The magnitude of these values is a measure of the accuracy, while the ratio of the basic and operative errors gives an idea of how well the technique is standardized. In both respects it appears superior to the now generally used test in the whole allantois.

\section{SUMMARY}

1. A method has been developed for the assay of antisera against influenza viruses.

2. Surviving bits of allantois-on-shell serve as host tissue, eighty to one hundred units being provided by a single egg. The test is set up in plastic trays, and uses a simple synthetic medium.

3. The method has worked equally well with the ten representative strains of influenza virus tested. It surpasses the orthodox techniques of neutralization in mice or whole eggs as regards sensitivity, accuracy and economy.

\section{REFERENCES}

Fazekas de St Groth, S. (1949). Austral. J. exp. Biol. 27, 65.

Fazekas de St Groth, S. \& Graham, D. M. (1954). Brit. J. exp. Path. 35, 60.

Fazekas de St Groth, S. \& White, D. O. (1958a). J. Hyg., Camb., 56, 151.

Fazekas de St Groth, S. \& White, D. O. (1958b). J. Hyg., Camb., 56, (in the Press).

Fazekas de St Groth, S. \& White, D. O. (1958c). J. Hyg., Camb., 56, (in the Press).

Fulton, F. (1952). J. Hyg., Camb., 50, 265.

Horsfall, F. L. (1939). J. exp. Med. 70, 209.

Tyrrell, D. A. J. \& Horsfall, F. L. (1953). J. exp. Med. 97, 845.

(MS. received for publication 17. XII. 57) 